\title{
微粉炭燃焼過程における灰粒子挙動の炭種依存性
}

\section{Effects of coal types on ash behaviors in pulverized coal combustion}

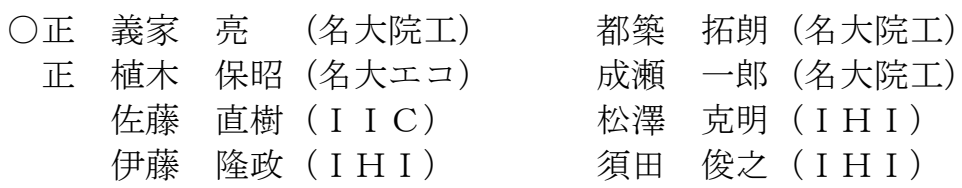

Ryo YOSHIIE, Takuro TSUZUKI, Yasuaki UEKI, Ichiro NARUSE, Nagoya University, Furo-cho, Chikusa-ku, Nagoya 464-8603, Japan Naoki SATO, IHI Inspection \& Instrumentation Co., Ltd., Shin-nakahara-cho, Isogo-ku, Yokohama, 235-8501, Japan

Yoshiaki MATSUZAWA, Takamasa ITO, Toshiyuki SUDA, IHI Corporation, Shin-Nakarara-cho 1, Isogo-ku, Yokohama, 235-8501, Japan

Key Words: Pulverized Coal Combustion, Included and Excluded Minerals, Ash Fragmentation and Coagulation

\section{1. 諸言}

近年，低品位炭の有効活用の観点から，既存の微粉炭燃焼 ボイラにおいても多炭種多様性への対応が求められている. しかし, 各ボイラの設計炭の許容範囲を逸脱する炭種を燃焼 させる場合, 炉内のスラッギングやファウリングといった灰 溶融性および付着性に由来するトラブルの抑制が大きな課 題となる ${ }^{(1)}$. よって, 本研究では炭種に応じた石炭燃焼過程 における無機成分粒子の挙動解明を目的として, 低融点, 中 融点, 高融点灰分の 3 種の石炭について, 電気加熱式ドロッ プチューブ型燃焼炬による燃焼実験を行った，そして炬内複 数点で炭素変換率の異なるチャーを採取して, CCSEM (Computer Controlled Scanning Electron Microscope) による灰 粒子の形態分析を施すことによって, 灰の凝集挙動を決める 大きな因子とされている Included Mineral と Excluded Mineral への分配について調べた.

\section{2. 石炭燃焼実験とチャー試料の採取}

\section{1 石炭試料}

本研究で使用した石炭の軟化点，溶融点，流下点を Table1 に示す. Coal K が低融点, Coal F が中融点, Coal A が高融 点の灰分を持つ石炭となっている. 灰分は重量比で Coal K が $13.8 \%$ ，Coal F が $8.5 \%$ ，Coal A が $12.18 \%$ 含んでいる。石 炭は $0.297 \mathrm{~m} / \mathrm{m}$ のふるいにかけた後，実験を行っている.

Table 1 Melting points of ash in coal samples

\begin{tabular}{|c|r||c|c|c|}
\hline & & Coal A & Coal F & Coal K \\
\hline \hline 軟化点 & ${ }^{\circ} \mathrm{C}$ & 1087 & 1190 & 1160 \\
\hline 溶融点 & ${ }^{\circ} \mathrm{C}$ & $>1550$ & 1300 & 1210 \\
\hline 流下点 & ${ }^{\circ} \mathrm{C}$ & $>1550$ & 1490 & 1500 \\
\hline
\end{tabular}

\subsection{DTF 実験}

石炭は $0.297 \mathrm{~m} / \mathrm{m}$ のふるいにかけた後, 実験を行う。石 炭試料の燃焼には, Fig.1 の電気加熱式ドロップチューブフ アーネス（DTF）を用いる。炉壁温度は $1400^{\circ} \mathrm{C}$ ，チャー試料 は炬下方から挿入された等速吸引プローブにて採取される. 採取位置は反応開始となるインジェクタ先端より，100mm〜 $400 \mathrm{~mm}$ の範囲では $100 \mathrm{~mm}$ 刻み，400mm〜1300mm では $200 \mathrm{~mm}$ 刻みとする。これによってチャーの炭素変換率は 0 〜80\%の範囲をカバーできる. 採取されたチャー試料につい ては, 差動型示差熱天科（リガク TG8200）による灰重量分 析の結果から, アッシュトレーサー法を用いて炭素変換率を 評価する.

\section{3 チャーサンプリング結果}

Fig.2(a)〜(c)に Coal K，Coal F，Coal A それぞれの DTF 実
験から得られたチャーサンプルの炭素変換率評価結 果を示す. 横軸はインジェクタからの距離を表してお り，石炭粒子が反応管内を落下寸るにつれて燃焼反応 が進行する様子がわかる．左端の $0 \mathrm{~mm}$ の点は原炭で あり, 炭素変換率はゼロである。三種の石炭で幅広い 炭素変換率のチャーの採取に成功した。よって, 各石 炭試料について, 図中の丸印で囲んだ 4 点のチャー試 料を CCSEM 分析により, より詳細な灰粒子の解析を 行うことにした。

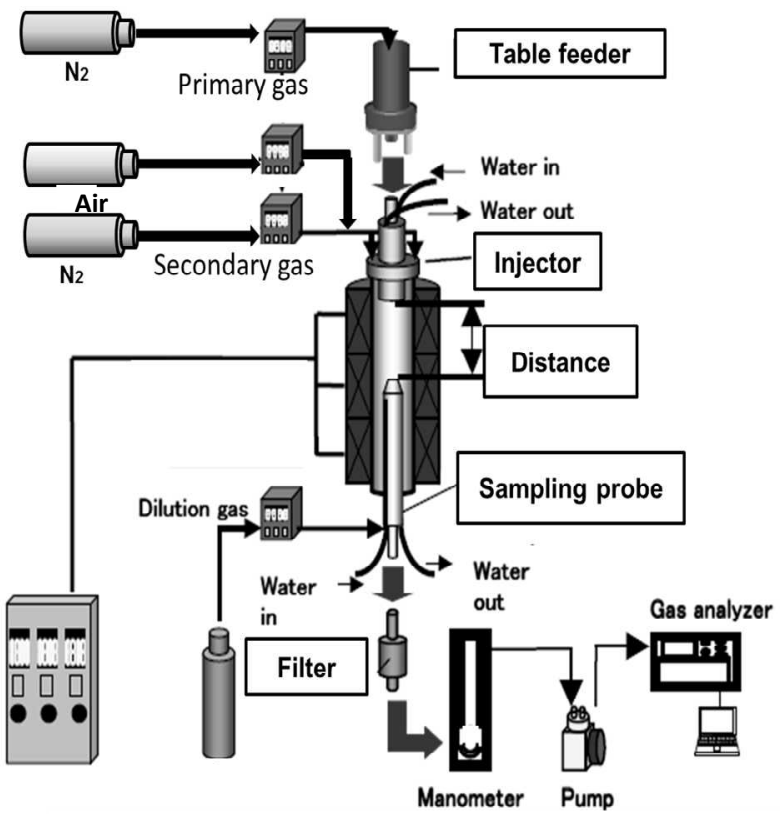

Fig. 1 Schematic of drop tube furnace for pulverized coal combustion experiment

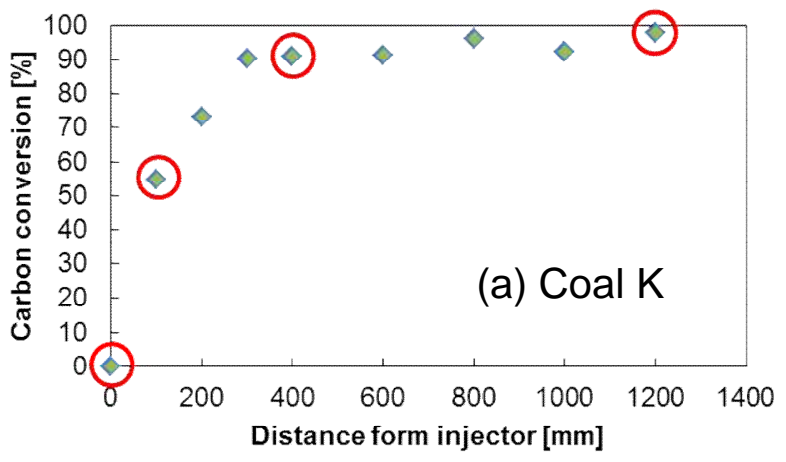



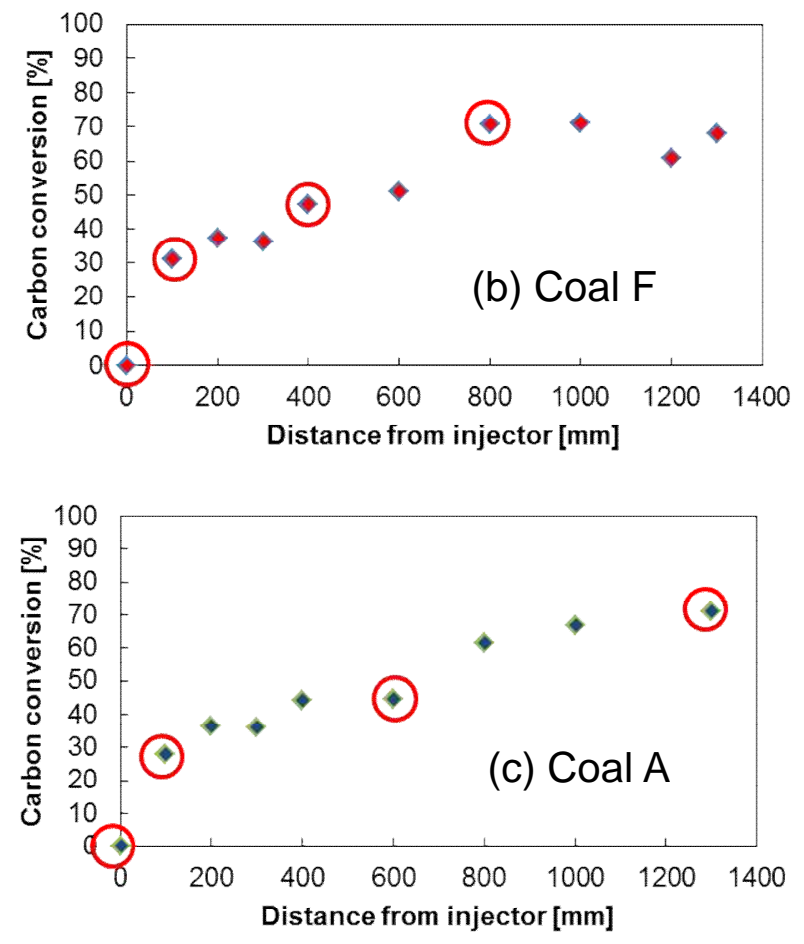

Fig. 2 Carbon conversions in coal particles through the reactor during the pulverized coal combustion for (a)coal K, (b)coal F and (c)coal A.

\section{3. 灰粒子の CCSEM 分析}

チャー試料に含まれる灰の形態を調べるため, CCSEM を 用いた粒子分析を行った。採取されたチャー粒子のうちの $100 \mathrm{mg}$ を測りとり, これをヒーターで $120^{\circ} \mathrm{C}$ に温めて液状と なったカルナパワックスと均一に混合して固めた。この底面 を研磨することによって SEM による観察視野とした。これ らの手法はすべて既報にならっている ${ }^{(2)}$.さらに視野内に含 まれる灰粒子すべてについて, 粒径を個別に評価し, 球形近 似によってその体積を求めて積算することにより，視野中灰 粒子の全体積を計算した. 一方, 視野内に含まれる灰粒子を, 単独で存在する Excluded Mineral と，未燃炭素成分に覆われ ている Included Mineral に分類して個別にカウントし，その 数を前述の灰粒子の全体積で割ることによって, 灰粒子単位 体積あたりの灰粒子構成数を Excluded Mineral と Included Mineral のそれぞれについて計算した．その結果を Fig.3(a)〜 (c)に示す. 燃焼反応場において, Included Mineral に起こる 現象は，熱により溶融した灰粒子が，接触することで一つに 溶けあう結合，マトリクスである炭素成分が燃えることによ り露出して, Excluded Mineral へと遷移する脱離などが考え られ, 主にその粒子の個数を減らす方向へ動く。一方,

Excluded Mineral については, Included Mineral からの遷移の 他に，高温の反応管内での熱衝撃による分裂，あるいはその 逆の凝集などが考えられる。これらの変化で Excluded Mineral の粒子数は増加するものと考えることができる ${ }^{(3)}$.こ れらの考えに基づいて Fig.3 を検証してみる. 三種の石炭試 料において Included Mineral は減少傾向にある。一方,

Excluded Mineral については, Fig.3(c)の Coal A が明らかに増 加傾向であるのに対して, Fig.3(a)(b)の Coal K と Coal F は増 加傾向が鈍い。これは，前節に述べた灰の融点に大きく影響 を受けていると考えられる。 すなわち, Coal K と Coal F は 灰融点が比較的低いため, Included Mineral の減少は粒子同士 の結合が支配的である。一方，灰融点の高い Coal A では脱 離が支配的であり, よって Excluded Mineral の増加率が高い.
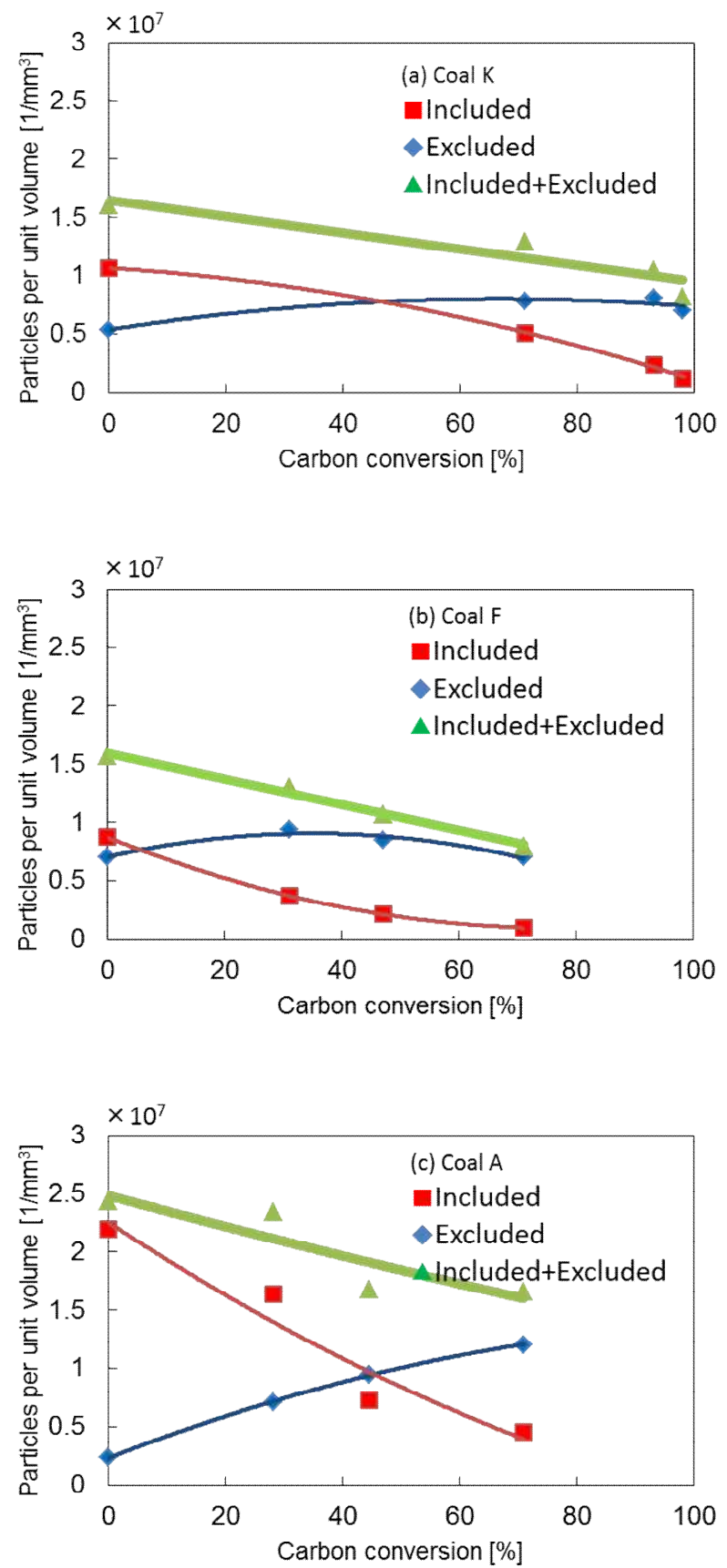

Fig. 3 Changes of the numbers of included and excluded minerals per unit volume ash with the progress of combustion

\section{4. 結言}

微粉炭燃焼条件における灰粒子の分裂凝集挙動について, Included Mineral, Excluded Mineral を個別に評価した。全体 として Included Mineral は灰粒子同士の結合や炭素マトリク ス成分からの脱落により，石炭粒子の燃焼反応が進むにつれ て減少する傾向にある。 その機構は Included Mineral 同士の 凝集と Excluded Mineral への脱離に大別され，その割合は灰 融点の影響を受ける。よって, Excluded Mineral は灰融点が 高いほどその増加傾向は高い.

\section{参考文献}

(1) I. Naruse, et al., Fuel 84 (2005) 405-410 04)

(2) D. Yu, et al., Energy Fuels 21 (2007) 468-476

(3) Y. Liu, et al., Energy \& Fuels 21 (2007) 461-467 